\title{
Introduction: Caregiving, Kinship, and the Making of Stories
}

\author{
Carol Schilling $^{1}$ (D) $\cdot$ Mark Osteen $^{1}$
}

Published online: 26 December 2016

(C) Springer Science+Business Media New York 2016

Paul Karasik and Judy Karasik's lovely joint memoir, The Ride Together, depicts their lives as the siblings of and caregivers for their autistic brother, David. A graphic artist, Paul presents his stories via panels of comics, while Judy offers a more conventional memoir in prose. David is fascinating. As a child and young man he re-enacts television shows, especially The Adventures of Superman, word for word. However, one of the pivotal moments in the memoir involves a different family member. In the chapter entitled "Independence," David has entered a day program, relieving teenaged Judy of her responsibilities for him. At the same time, her family members also care for her elderly grandfather, a former surgeon, and her severely disabled aunt. One day Judy comes home from school to find that the nurse they hired for her grandfather has been neglecting him. About suddenly needing to replace the nurse, Judy writes: "It wouldn't be until years later that I would learn how to lift someone, how to change a bed underneath someone, how to feed a grown person who ate only soft food. But that night I learned that a person needs to know these things, to be independent" (Karasik 2003, 96).

Her use of the word "independent" seems counterintuitive. Doesn't learning to lift, change a bed for, and feed someone imply the opposite of independence? In fact, her twist reveals a truth: independence requires us to acknowledge what Eva Feder Kittay calls "the fiction of our independence" and the biological innateness of dependency (1999, xiii, 29). That is, Judy learns that she isn't mature and fully human unless she knows how to care for others. Her discovery suggests that we can't recognize our connectedness until we're independent - of prejudice and misconceptions about people who need care and those who provide it.

We offer this passage and its inversion of the Western emphasis on independence as the touchstone for this Special Issue. Each of the essays included here in some way challenges the assumption of autonomy by witnessing and analyzing how those who give and receive care exercise multiple and collaborative agencies. Instead of presenting caregiving relations in the

Carol Schilling

cschilli@haverford.edu 
conventional framework in which a caregiver acts upon a person receiving care, these essayssome situated in personal experience - and poems call our attention to what Stacy Clifford Simplican calls "complex dependency." Her term reflects two central observations: that dependent persons can be both vulnerable and assertive and that the interests of carers and charges can "overlap and produce each other" (2015, 219, 221).

For example, Rachel Adams's essay on the eponymous testimonio Gaby Brimmer posits complex dependency as a model for both caregiving and life-writing. Because Brimmer lived with a severe form of cerebral palsy and relied upon her caregivers to help her move through each day, we might assume that her life and her story would exemplify conventional notions of dependency. But both her life and narrative display unexpected complexities. Brimmer's memoir (originally in Spanish) is written in multiple voiceshers, her mother's, and her employed caregiver's - all arranged in a narrative shaped by journalist Elena Poniatowska. No single voice here would have emerged without a complex collaboration dependent on, among other interests and needs, Brimmer's need for her caregivers' labors, the caregivers' need for Brimmer's thoughts and directions, and the journalist's need for all their voices and cooperation. As a collaborative project, the book makes all their labors visible and instantiates in both form and content an example of interdependence. As Margrit Shildrick writes, rather than diminishing us, dependency instigates "new becomings with others" $(2015,24)$.

Similarly, Carol Schilling's reading of Elegy for Iris argues against the view that John Bayley was guilty of colonizing or appropriating for his own ends the voice and story of his wife, acclaimed philosopher and novelist Iris Murdoch. Schilling writes that their relationship was mutually transformative and dynamic. In her state of dementia, Murdoch "colonized" Bayley's mind and life story, while his memoir seeks to do justice to her illness, her values, and her past accomplishments. As he attentively cared for Iris, Bayley altered his way of being and remade the conventional elegy in response to the kind of ambiguous loss he experienced. The ethical question of speaking for or "colonizing" another also underlies Mark Osteen's first-person essay, "Pas de Deux," in which a parent writes for and speculates about the thoughts of a non-verbal loved one. How can such a parent avoid being presumptuous? Osteen suggests that he evades that hazard by paying careful attention to his autistic son Cameron's non-verbal language, by honoring his son's preferences and, perhaps most importantly, by being willing to learn from, as well as teach, his son. Osteen shows how caring for-and listening toCameron has changed him both personally and professionally: enhancing his pedagogy, refining his understanding of his students, and revitalizing his scholarship.

Holly Allen raises another ethical question about representing what Eva Feder Kittay (1999) calls affectional labor: why should we assume that caring for dependents should be the almost exclusive responsibility of members of the dependent's household, especially female members? Allen shows how, when autistic children do violence to their mothers, gendered stereotypes of caregivers encourage media producers and consumers to demonize the mothers. That is, the violence visited upon these mothers is presented, absurdly, as their own fault. Popular narratives, whether in fictional films or news reportage, provide little or no consideration of the larger social problems and gaps that such incidents expose. Allen asks, for example, why there isn't adequate social support and real resources available to disabled children and the adults they become. Why do caregiving responsibilities fall entirely on 
families? What care arrangements beyond genetic or legal families functioning as autonomous units can we imagine and implement?

Libbie Rifkin's essay offers one answer to that question in her analysis of poet Eileen Myles's autobiographical short story, "Chelsea Girls," in relation to her life in the East Village during the 1970s. In considering how the young writer cared for the established poet James Schuyler when he became disabled, Rifkin writes about dependency care as a form of queer kinship. That is, Myles and Schuyler each chose to enter their care giving and receiving relationship, which was mutually dependent and mutually beneficial. Thus Rifkin's contribution exemplifies the principle of interdependence. Certainly Schuyler benefitted from Myles's presence and care. But she too acquired necessary employment and valuable confidence when Schuyler served as a mentor and model for her career as a poet. Myles paradoxically acquired financial and artistic independence by cultivating interdependence.

Finally, just as these writers question and disrupt conventional ideas of dependency, kinship, familial responsibilities, and gender roles, some of the essays themselves subvert generic conventions that draw a hard line between the scholarly and the personal. For example, Osteen crafts a hybrid form of personal and scholarly essay in his autobiographical narrative about incorporating his experiences caring for his son into new forms of pedagogy. Michele Taylor, too, reveals the crossing vectors in her professional and personal lives. Her essay reflects on how her scholarship in architectural history, especially the nineteenth-century architects influenced by theories of therapeutic environments, alerted her to the needs of her debilitated father. In the process, she reconstructed her own intellectual paradigms. Similarly, Joanne Jacobson's self-reflective writing on publishing essays about her mother's illness is informed by her knowledge of life-writing theory. Writing about her mother quickened a series of ethical questions about whether her essays compromised the privileged intimacy of familial caregiving and about whether the creative labor of writing might also be a labor of caring. Because Jacobson explicitly asks questions instigated by the interdependencies central to our humanity that carers and recipients, storytellers and readers cannot avoid, we place her essay first. As with the other essays, we come to understand that caregiving, like writing, is a dynamic process of constant revision.

In addition to the scholarly essays, we're pleased to include contributions from those who have combined the labor of care with the labor of the creative imagination. In one case, sisters Devan Stahl and Darian Goldin Stahl exemplify an unusual form of interdependency. When clinical ethicist Devan was diagnosed with multiple sclerosis, her sister Darian turned her sibling's medical images into a series of prints called "Habitus." Both write here about how Devan's response to her diagnosis and Darian's printmaking depended on each other, not only to help Devan "resist the medical gaze" but also to transform both "the trajectory of [Darian's] artwork" and their relationship. Three contributors-Johanna Shapiro, Charles Ethan Paccione, and Teresa Maginess-have transformed their caregiving into poems that reflect on their complex dependencies.

All of the contributors here, in fact, have a personal stake in their research and writing about caregiving because each of us is a caregiver, whether of parents (Jacobson, Taylor, HursonMaginess, Shapiro), disabled children (Schilling, Osteen, Adams, Rifkin, Allen), a grandparent (Paccione), or a sibling (Stahl). In that regard, we offer our lives and works as examples of how the personal and the professional, writing and caring, caring and learning, are themselves interdependent on each other and on the world we all inhabit. 


\section{References}

Karasik, Paul and Judy Karasik. 2003. The Ride Together: A Brother and Sister's Memoir of Autism in the Family. New York: Washington Square Press.

Kittay, Eva Feder. 1999. Love's Labor: Essays on Women, Equality, and Dependency. New York and London: Routledge.

Shildrick, Margrit. 2015. “'Why Should Our Bodies End at the Skin?': Embodiment, Boundaries, and Somatechnics." Hypatia 30 (1): 13-29.

Simplican, Stacy Clifford. 2015. "Care, Disability, and Violence: Theorizing Complex Dependency in Eva Kittay and Judith Butler." Hypatia 30 (1): 217-233. 